\title{
KORNELA I LUDWIKA ZIELONKÓW DROGA NA SYBERIĘ ROSJA W OCZACH ZESŁAŃCÓW POSTYCZNIOWYCH*
}

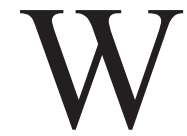

ielu badaczy poruszało tematykę drogi na zesłanie. W wieku XIX chociażby N.K. Jadrincew ${ }^{1}$ i S. Maksimow ${ }^{2}$, którzy poruszali tę kwestię niemal na „świeżo”, podobnie jak Zygmunt Librowicz ${ }^{3}$. O etapach wspominali późniejsi badacze m.in. Michał Janik ${ }^{4}$ i Antoni Kuczyński ${ }^{5}$, choć nie w kwestii ogólnej, a raczej w odniesieniu do konkretnych zesłańców. Również Elżbieta Kaczyńska ${ }^{6}$ i Wiktoria Śliwowska podejmowały problem etapów w swoich pracach. Szczególnie zaś druga z nich, w Ucieczkach z Sybiru ${ }^{7}$, nakreśliła także kwestię powrotu z zesłania. Wspomnieć można, że problem drogi na zesłanie cieszył się również dużym zainteresowaniem już na początku XX w., czego wyrazem była wydana w 1916 r. książka - zbiór fragmentów wspomnień, pod tytułem Etapami na Syberye $e^{8}$. Przedstawiono tam fragmenty wspomnień m.in. omawianych tutaj Ludwika i Kornela Zielonków, a ponadto Agatona Gillera, Konstantego Wolickiego czy Apolinarego Świętorzeckiego.

W niniejszym artykule chcę przedstawić drogę na Syberię, taką jak ją widzieli Ludwik Zielonka oraz jego brat Kornel. Chciałbym również nakreślić nieco szerszy kontekst za pomocą relacji kilku wybranych pamiętnikarzy zesłańców.

W tym miejscu należy zadać ważne pytanie, a mianowicie czym była Syberia w świadomości skazanych na nią zesłańców? W sensie geograficznym obszar ten nie do końca pokrywał się z tym, co zesłańcy rozumieli przez pojęcie „Sybiru”.

\footnotetext{
* Niniejszy artykuł powstał w ramach projektu Narodowego Programu Rozwoju Humanistyki pt. „Polscy zesłańcy na Syberii Zachodniej w drugiej połowie XVIII - XIX wieku w oczach Rosjan i ludności syberyjskiej”, umowa Nr 0098/NPRH3/H12/82/2014.

${ }^{1}$ Н.К. Ядринцев, Сибирь как колония, Санкт-Петербург 1892.

2 S. Maksimow, Syberya i ciężkie roboty, Warszawa 1899.

3 Z. Librowicz, Polacy w Syberii, Kraków 1884.

${ }^{4}$ M. Janik, Dzieje Polaków na Syberii, Kraków 1928.

${ }^{5}$ A. Kuczyński, Syberia. Czterysta lat polskiej diaspory, Wrocław 1993.

${ }^{6}$ E. Kaczyńska, Syberia: największe więzienie świata (1815-1914), Warszawa 1991.

7 W. Śliwowska, Ucieczki z Sybiru, Warszawa 2005.

${ }^{8}$ Etapami na Syberyę. Obrazy i wspomnienia, Warszawa 1916.
} 
W takim rozumieniu, pojęcie to zawierało w sobie również Kaukaz, Daleki Wschód, stepy kirgiskie, a więc dzisiejszy Kazachstan, a także często północne gubernie Rosji. Jak pisze W. Śliwowska, informacje na temat Syberii i losu zesłanych tam Polaków długo były zupełnie nieznane ${ }^{9}$. Jednocześnie zaczęła kształtować się czarna legenda Sybiru, jako miejsca zsyłek i osiedlania przeciwników rządów kolejnych carów, w tym przedstawicieli narodów zamieszkujących Rosję, a podejmujących walkę o suwerenność. Narosło przy tym szereg tzw. mitów Sybiru, jedynie częściowo znajdujących uzasadnienie w rzeczywistości. Choć czy aby na pewno tylko częściowo? W takim klimacie kolejne pokolenia w ciągu XVIII i XIX w. „wyruszały na Wschód”, w głąb ogromnego Imperium Rosyjskiego.

W takim wypadku nie może więc dziwić fakt, że w wielu wspomnieniach i opisach drogi na Syberię, jasno zaznacza się obawa, strach i niepewność. Nie wiedziano, co czeka zesłańców w owym syberyjskim piekle, jak to sobie wyobrażano. Nie mniej tajemniczą zdawała się sama podróż w tak odległe miejsce. Stwierdzić też można, że uciążliwość podróży była tak wielka, że nawet katorga zdawała się być potem ulgą. W świetle literatury przedmiotu i analizy pamiętników można wręcz konstatować, że niejednemu zesłańcowi droga na Syberię wbiła się w pamięć silniej, niż sam pobyt na zesłaniu.

Warto tutaj wspomnieć o kwestiach technicznych, a więc o stronie organizowania transportu więźniów. Punkty postoju dzieliło od 130 do nawet $330 \mathrm{~km}$. Dziennie, w przeciętnych warunkach, przebywano od 28 do $30 \mathrm{~km}$. Na etap zatem często przybywano po około 10 dniach wędrówki. Noce, w miarę możliwości, spędzano w barakach, prymitywnych zagrodach, a czasem w chatach chłopskich. Teoretycznie etapy miały przynieść zesłańcom odpoczynek, w praktyce jednak zazwyczaj przynosiły nowe pasmo udręk w postaci małych cel, marnych posiłków i uciążliwych pasożytów ${ }^{10}$.

Prześledźmy tę drogę na Sybir zobrazowaną przez braci Zielonków, zesłańców postyczniowych. Jedynie krótko (gdyż nie jest przedmiotem mojego opracowania odtwarzanie ich biografii) kim byli bohaterowie niniejszego tekstu. Ludwik Jastrzębiec Zielonka urodził się w 1835 r. Był najstarszym z czterech braci. Brał udział w powstaniu styczniowym, gdzie, jak wspomina jego brat Kornel, dosłużył się rangi majora ${ }^{11}$. Był dowódcą oddziału w bitwie pod Fajsławicami 15 sierpnia 1863 r., gdzie wzięty został do niewoli. Więziony w Cytadeli Warszawskiej, 2 listopada 1863 r. skazany został na 8 lat robót do kopalń Nerczyńskich w Kraju Zabajkalskim. Po zesłaniu osiadł w Galicji, gdzie zmarł

\footnotetext{
9 Zob.: W. Śliwowska, Ucieczki..., passim.

${ }^{10}$ Zob.: E. Kaczyńska, Syberia..., passim.

${ }^{11}$ K. Zielonka, Wspomnienia z powstania 1863 roku i z życia na wygnaniu w Syberyi, Lwów
} 1913, s. 3. 
w 1897 r. Pochowany został we Lwowie na Cmentarzu Łyczakowskim ${ }^{12}$. Jego młodszy brat Kornel walczył w powstaniu styczniowym pod dowództwem płk. Dionizego Czachowskiego i Karola Kality „Rębajły”. Szybko jednak dostał się do niewoli w bitwie pod Jeziorkiem (29 października 1863). Wyrokiem sądu wojennego w Pskowie skazany na zesłanie na Syberię. Na mocy manifestu carskiego, jako poddany austriacki, został uwolniony z zesłania i w 1869 r. powrócił do Galicji. W 1913 r. we Lwowie opublikował swoje wspomnienia ${ }^{13}$.

Udział w powstaniu i pobyt na zesłaniu stał się motywem do napisania przez nich wspomnień. Pamiętnik L. Zielonki podzielony został na trzy części: Obrazki z katorgi, Posielenie i Powrót do kraju. Omawiając tematykę drogi na zesłanie interesować nas będzie przede wszystkim część pierwsza.

W swoim pamiętniku Ludwik rozpoczął opis od rozdziału nazwanego Etapy. Już pierwsze dwa akapity nakreślają trudną sytuację, w jakiej znalazł się L. Zielonka. Jego wędrówka rozpoczęła się zimą 1863 r., dokładnie w drugi dzień świąt Bożego Narodzenia. Oprócz niego w drogę wyruszyło 35 innych Polaków i, jak wspomina, z ,[...] czterystoma Moskiewskimi zbrodniarzami”14. Na wstępie zaznacza więc, że więźniowie nie byli sobie równi. Oddziela ,moskiewskich zbrodniarzy” od „Polaków, tak nazwanych politycznych przestępców”15.

W opisie L. Zielonki jednocześnie uderza pewna beznadziejność całej sytuacji. Zadaje przepełnione cierpieniem pytanie: ,Jakim Bożym cudem przebyliśmy pierwszy półetap?". Odpowiada sobie, że nie ma pojęcia, jak im to udało się wśród świstu nahajek kozackich i brzęku kajdan. Doszli późną nocą do ,,[...] jakiejś wioski zasypanej śniegiem”. Stłoczeni jak „bydło” spędzili we wspomnianej wiosce noc. Obrazu beznadziei dopełniło ,posilenie się kawałkiem razowego chleba”. Podsumowując pierwszy dzień w drodze, L. Zielonka tak przedstawia poranek:

Przetarłem oczy, zerwałem się, oprzytomniałem, i dopiero teraz całe nasze opłakane położenie stanęło mi jasno przed oczami. Był to pierwszy półetap, pierwszy nocny odpoczynek, początek naszej długiej wędrówki przez odludny step Sybiru ${ }^{16}$.

Wydaje się, że do tego przepełnionego emocjonalnie opisu nic dodawać nie trzeba. W sposób jasny i klarowny L. Zielonka charakteryzuje pierwsze wrażenia z drogi na zesłanie. Nie był to, rzecz jasna, jedyny taki przypadek. Wielu zesłańców wszak w ten sposób postrzegało doświadczenie wędrówki na zesłanie.

L. Zielonka, oprócz umiejętnego charakteryzowania nędzy i cierpienia w codzienności etapowej, potrafi także z ironią odnieść się do niektórych wyda-

${ }^{12}$ L. Zielonka, Wspomnienia z Syberji od r. 1863-1869, Lwów 1886, passim; S. Król, Cytadela Warszawska, Warszawa 1978.

${ }^{13} \mathrm{~K}$. Zielonka, Wspomnienia..., passim.

${ }^{14}$ L. Zielonka, Wspomnienia..., s. 1.

15 Tamże, s. 1.

16 Tamże, s. 2. 
rzeń, których był uczestnikiem i świadkiem. I tak, partia, dotarłszy do miejsca, w którym miała nocować, zatrzymała się na polecenie zastępcy naczelnika. Rozkazał on ustawić się w trzech rzędach by mógł policzyć ludzi w partii. Warto przytoczyć, w jaki sposób L. Zielonka ową sytuację opisuje:

Pan feldwebel zaczyna rachować od prawego, raz, dwa, trzy i już doszedł do 79, ale jakie nieszczęście, z tej to liczby zeszedł do 60, a straciwszy dalszy rachunek zaczyna na nowo. [...] ów wielki człowiek [...] rachuje na nowo - skończył. Chwała Bogu, krzyknęliśmy wszyscy, ale była to radość tylko chwilowa, bo zapomnieliśmy, że trzeba będzie jeszcze te liczby przez 3 pomnożyć, a tego trudno wymagać od feldwebela, a nawet od niejednego oficera etapowego, tak daleko nie sięga oświata tamtejszych moskiewskich dostojników, to też i nasz komendant natężył swój umysł, czoło i brwi zmarszczył, palce u rąk puścił machinalnie w ruch i po długim takiem natężaniu mózgownicy, przyłożył palec do czoła, podumał, pokiwał, i rzekł sam do siebie: „o, znajdą się wszyscy”"

Tam też spotkało L. Zielonkę i ich towarzyszy dość duże szczęście, bowiem podchmielony naczelnik etapu, stał się niezwykle wylewny, przez co zapewniał wszystkich Polaków o swojej sympatii i o tym, że jest liberałem, Rosjaninem wolnomyślicielem. Tym samym zaprosił Polaków na wódkę. Tam też poczęstowani zostali przez żonę naczelnika trunkiem podawanym w filiżankach i zagryzką w postaci pieczonego grochu. L. Zielonka nie ukrywał zadowolenia $\mathrm{z}$ tego zaproszenia, bowiem przekonany był, że w ten sposób zaoszczędzi na śniadanie. Okazało się jednak, że naczelnikowa zażyczyła sobie za wódkę i groch po 15 kopiejek „z ryła”, czyli od osoby ${ }^{18}$.

Ten dzień L. Zielonka podsumował przytaczając historię dziecka, które zmarło z zimna i głodu, a którego ciało zabrano od matki i więcej nie pozwolono jej go zobaczyć. Wyraził jednocześnie wątpliwość by nawet w najdzikszym kraju coś podobnego mogło się wydarzyćc 19 .

Cały drugi rozdział autor wspomnień poświęca problematyce fałszowania pieniędzy w więzieniach i na etapach syberyjskich, o czym pisze, że proceder ten jest tak rozpowszechniony, że naczelnicy więzień dorabiają się nieraz wielkich majątków.

W międzyczasie L. Zielonka nakreśla dobrze znany obraz lżenia partii zesłańców przez „zbydlęcony lud miasta Moskwy”20. Nie omieszkano również użyć kamieni i ostrych słów wobec skazańców. Z Moskwy koleją udali się do Niżnego Nowogrodu, a stamtąd pocztą do Tobolska, do którego jechano 20 dni. Odpoczynku zaznali zesłańcy ledwie dwa razy po 6 godzin w Permie i Jekaterynburgu. Przebywano, jak pisze L. Zielonka, około 25 mil dziennie.

\footnotetext{
17 Tamże, s. 7.

18 Tamże, s. 16-18.

19 Tamże, s. 19.

20 Tamże, s. 24.
} 
W tym miejscu warto pochylić się nad charakteryzowanym przez Zielonkę gubernatorem tobolskim - Aleksandrem Despot-Zenowiczem ${ }^{21}$. Autor tak opisuje gubernatora:

[...] znany ze swej prawości, nieskazitelnego charakteru i nadzwyczaj wielkiej energii - trzydziestokilkuletni, szlachetnych i nader ujmujących rysów - Despot Zenowicz, bicz boży wszelkich nadużyć i złodziejstw, a prawdziwy dobrodziej tamecznego mieszczaństwa i chłopstwa, osobliwie tych ostatnich brał pod swoją szczególną opiekę. Nie dziw więc, że wszyscy sowietnicy, strapczy, sprawniki, zasidatele i cała różnorodna zgraja „czynowników" - nienawidziła gubernatora ${ }^{22}$.

Poznanie i scharakteryzowanie postaci Despot-Zenowicza zdaje się być punktem wspólnym wielu wspomnień zesłańców postyczniowych.

L. Zielonka zajmuje się następnie znów problemem fałszowania pieniędzy w Tobolsku, który to proceder rozwijał się pomimo „bystrego wzroku gubernatora". W tym fragmencie wspomnień weteran powstania zawiera również istotną informację dotyczącą tego, jaki stosunek do systemu carskiego mieli niektórzy urzędnicy. Cytuje jednego z nich w sytuacji, gdy ten zaproponował im zakup fałszowanych pieniędzy. Czynownik ów, na oburzenie zesłańców, zareagował szyderczym stwierdzeniem:

[...] toż u nas rzecz zwyczajna, kto by bowiem chciał naszemu carowi rzetelnie służyć, diabli by go wzięli, albo by musiał wziąć torbę na plecy i kij do ręki i pójść po żebranym chlebie. [...] gdy tak pobędziecie lat kilka między nami - zmienicie się i przekonacie się, że prawdą i rzetelnością w naszej Moskwie daleko nie zajdziecie ${ }^{23}$.

Wracając już do drogi na miejsce ciężkich robót - partia zesłańców, w której był L. Zielonka dotarła do Tomska w tydzień po świętach Wielkanocnych $1864 \mathrm{r}$. Tam też przebywali w więzieniu przez cztery następne tygodnie.

Po tym okresie nowa partia aresztancka w liczbie 400 osób wyruszyła do Krasnojarska, dokąd dotarła w maju. W Irkucku zaś L. Zielonka znalazł się pod koniec września, jak wspomina - wynędzniały i głodny. Część z jego partii wysłano do Usola, część natomiast, w tym i L. Zielonkę, do Pietrowska. Następnie przeniesiony został do Czyty, a pod koniec 1864 r. dotarł już na roboty do kopalń Nerczyńskich. Nie był to jednak koniec drogi Ludwika, bowiem w październiku 1866 r. został „oddelegowany” do kopalń srebra w Kadai.

Bardziej rozbudowany i szczegółowy obraz początku drogi na Syberię przedstawia Kornel Zielonka. Młodszy brat Ludwika, który poszedł do powstania jesie-

${ }^{21}$ Zob. E. Semenov, Ku pamięci Aleksandra Despot Zenowicza w Kiachcie, „Rodacy. Pismo Syberyjskie Kongresu Polaków w Rosji”, nr 1 (54) / 2011 s. 8-9, rodacynasyberii.pl. [dostęp 21 XI 2015].

${ }^{22}$ Tamże, s. 26.

${ }^{23}$ Tamże, s. 28-29. 
nią 1863 r., szybko dostał się do rosyjskiej niewoli. Więziony był w Kielcach, Radomiu i Cytadeli Warszawskiej. Skazany został na osiedlenie we wsi Kujada, a następnie przeniesiony do Tugutui.

Jak z kolei wyglądała jego droga na zesłanie? Wysłany najpierw do Petersburga, a stamtąd do Moskwy, by następnie dotrzeć do Włodzimierza, gdzie był sądzony i skazany na osiedlenie we Wschodniej Syberii. Podróż etapami jego partia rozpoczęła od Niżnego Nowogrodu. Następnym przystankiem był Kazań, który, jak Kornel zaznacza, był wypełniony ludnością tatarską wyznania mahometańskiego, mową, ubiorem i kulturą różniącą się od narodów zamieszkujących Rosję. Z przybycia do Kazania jednozdaniową relację K. Zielonka zdaje następująco: , ,...] gdzieżby nas indziej jak nie do tiurmy wpakowano - i tam dłuższy czas zatrzymano" ${ }^{24}$.

Wcześniej jednak Kornel podaje opis Moskwy, z którego wyłania się obraz szacunku dla ogromu miasta. Ponadto autor ukazuje zrozumienie dla rosyjskiego dziedzictwa historycznego, zawierając niezwykle ciekawe porównania w swym opisie:

Przechodzimy obok sławnego Kremlu, dawnej rezydencji carów. Sam Kremel bardzo rozległy stanowi jakby osobne miasto w Moskwie. Jak dla nas Wawel, tak dla Moskali Kremel ma historyczne znaczenie i poszanowanie ${ }^{25}$.

Dalej wdaje się w opis np. grubości murów, losów Moskwy m.in. w trakcie wojen napoleońskich, porównanie wielkości z innymi miastami Europy, życie miasta, zajęcia jego mieszkańców. Wskazuje również na moskiewską sferę sacrum, pisząc, że „Moskwa dla Rosyanina, co Mekka dla Turka”. Zatrzymując się przy wrażeniach z Moskwy wyniesionych przez obu braci, należy zaznaczyć, że Ludwik zapamiętał głównie tłum gapiów, który rzucał w zesłańców ostrymi kamieniami i słowami. Opis ten jest krótki, przepełniony emocjami i żalem, złością i bezsilnością. Kornel natomiast zdaje się czerpać przyjemność z pobytu w Moskwie, pomimo okoliczności w jakich się tam znalazł. Jest zachwycony ludźmi, architekturą, dziedzictwem historycznym tego miejsca ${ }^{26}$.

K. Zielonka, co trzeba przyznać, jest w swej narracji jednocześnie doskonałym obserwatorem, zainteresowanym wieloma aspektami miejsc, które mijał. Często, choć w kilku zdaniach, opisuje i nazywa ludy zamieszkujące dany teren, pisze jakim językiem się posługiwali i, w miarę możliwości, wskazuje na charakterystyczne elementy ich kultury. Wydaje się, że Kornel stara się być swego rodzaju etnologiem-amatorem. Przechodząc przez gubernię wiatską, dochodząc do Permu, a następnie do Konguru, opisuje ludy tam żyjące, ukształtowanie terenu, klimat.

\footnotetext{
${ }^{24}$ K. Zielonka, Wspomnienia..., s. 53.

25 Tamże, s. 45.

${ }^{26}$ Tamże, s. 45-46.
} 
Z jego wspomnień można dowiedzieć się wiele o ówczesnej rzeczywistości, bowiem ujmowana była ona przez Kornela wieloaspektowo ${ }^{27}$.

Ważnym momentem w wędrówce każdego chyba zesłańca było przebycie granicy Europy i Azji. W momencie przekroczenia tej granicy, skazańcy stawiali stopy już na Syberii. Opis K. Zielonki związany z tym momentem na drodze zesłańca, przekraczania owej granicy, jest wyjątkowy i z całą pewnością warto go tutaj przytoczyć:

Jesteśmy już w ostatniej stacji etapowej w Rosyi. Stąd wyruszamy rano i przychodzimy do słupa granicznego między Europą i Azyą. Słup ten, murowany, czworograniasty, 5-6 metrów wysoki, z jednej strony herbem guberni permskiej europejskiej, a z drugiej tobolskiej azyatyckiej oznaczony. Tu pogranicze Syberyi ${ }^{28}$.

I dalej już przechodzi do bardzo interesującej, w kontekście niniejszych rozważań, kwestii funkcjonowania pojęcia „Sybir” w świadomości zesłańców. Fragment ten, jest na tyle interesujący i obrazujący, że warto go również przytoczyć:

„Sybir!” To wyraz nam nie obcy, z krwawych liter złożony! A ten słup? - to świadek przesuwających się obok niego tylu istot nieszczęśliwych z szarpiącym ich bólem - tym towarzyszem im niedostępnym ${ }^{29}$.

Wzrusza się dalej K. Zielonka mocno nad losem swoim, swoich współtowarzyszy i setek cierpiących niedolę, przekraczających tę granicę: „,[...] a nawet temu, co nigdy nie płakał, łzę wyciska" 30 .

Następnym przystankiem po Permie był Jekaterynburg, a potem Tiumeń i ostatecznie Tobolsk, gdzie poznał Kornel wspomnianego już gubernatora tobolskiego Despot Zenowicza. Jest to kolejny punkt, który warto zestawić z opisem Ludwika Zielonki. Oba opisy, w ogólności, są do siebie bardzo podobne, toteż warto go tutaj przytoczyć, by przekonać się, że gubernator wśród zesłańców cieszył się wielkim szacunkiem:

[...] Polak, jeszcze młody człowiek jak na takiem stanowisku, około czterdziestu paru lat; szlachetnych rysów twarzy, elegancki, w obejściu ujmujący, bardzo prawego charakteru, a przytem energiczny. [...] Urzędnicy, jemu podwładni, bardzo się go bali, bo ostro ich trzymał i wszelkie nadużycia srogo karcił31.

Nie ominęło K. Zielonki także doświadczenie okropności etapowych, takich jak np. smród rozchodzący się z kloaki, zapach brudnych ciała, że aż „[...] zdaje się, iż jednego atomu czystego powietrza nie ma". Problemem był ponadto sam marsz, w trakcie którego ,[...] zdarzało się, że słota a bywało i ulewa przemoczy

\footnotetext{
27 Tamże, passim.

28 Tamże, s. 55-56.

29 Tamże, s. 56.

${ }^{30}$ Tamże, s. 56.

31 Tamże, s. 60.
} 
do nitki”. To tylko kilka z wielu niedogodności, jakie znosić mieli skazańcy w drodze na przeznaczone im miejsce. Nie mniej uciążliwe było

[...] ciągłe stykanie się z konwojem, z tem żołdactwem gburowatem, a jeszcze gorzej, gdy trafił się komendant od konwoju grubianin, awanturnik, złośliwy, a często i pijak ${ }^{32}$.

Ważny jest również fragment niejako konkludujący proces wędrówki na Syberię:

Gdyby mogło być zmazanie wszystkich win człowieka przez pokutę, to wskazana pokuta przejściem przez etapy - wystarczyłaby na to. Gdyby żył w dobie tych wędrówek Dante i przeszedłby się etapami, nie szukałby w fantazji tematu do stworzenia dzieła swego o „Piekle”, bo na ziemi po drodze etapów znalazłby go! ${ }^{33}$.

Z Tobolska kibitkami wyruszyła partia K. Zielonki do Tomska, stamtąd do Krasnojarska, by przeprawić się przez Jenisej. Następnym przystankiem był Irkuck, do którego drogę znosić musiał Kornel w towarzystwie srogiej zimy. Z Irkucka już rozesłano skazańców do wsi im przeznaczonych.

Z obu pamiętników braci, odbywających drogę na zesłanie osobno, wyłania się bezwzględnie różnorodny obraz przymusowej peregrynacji na Syberię. Podczas, gdy Ludwik skupia się przede wszystkim na emocjach w dużej mierze negatywnych i ironizowaniu niektórych sytuacji, to z kolei Kornel obserwuje i zdaje poetycką wręcz relację, nie pomijając, rzecz jasna, emocji jakie odczuwał, jednak stara się nie eksponować ich w tak wyraźny sposób jak brat. Oba te opisy dają wyobrażenie o trudnościach etapowych, o życiu na wygnaniu, o tęsknocie, ale i pięknie okolicznej przyrody. Nie można jednak uogólniać w przedstawianiu problematyki drogi na Syberię. Każdy z pamiętników należy traktować indywidualnie, osobno rozpatrywać istotne informacje, a jednocześnie szukać punktów wspólnych dla postrzeganej przez zesłańców rzeczywistości.

Tytułem porównania przytoczę inne przykłady opisów drogi na zesłanie, odnosząc je do wrażeń pozostawionych na kartach swoich wspomnień przez braci Zielonków. Pominę cały proces ich wędrówki, uwypuklając jedynie najistotniejsze, moim zdaniem, elementy, które dadzą, przynajmniej częściowy, uzupełniony lub podobny obraz i odpowiedź czym dla każdego z nich była droga na Syberię.

I tak na przykład, Wacław Lasocki w swoim pamiętniku wdaje się w relację z etapów i samej podróży, zaznaczając, że opisy piekła Dantego bledną w porównaniu z podróżowaniem traktem syberyjskim wraz z więźniami cywilnymi i kryminalnymi (tutaj podobieństwo z opisem Kornela Zielonki w określeniu drogi na Syberię jako piekła):

\footnotetext{
${ }^{32}$ Tamże, s. 62-63.

33 Tamże, s. 67.
} 
Więźniowie cywilni i kryminalni stanowią z małemi wyjątkami stek brudów moralnych. Wszyscy z braku środków skazani są na konieczne wytwarzanie wkoło siebie brudnej cuchnącej atmosfery. [...] Dodajmy tu, że oddech ich i gatunek tytoniu, który palą, są nową formą męczarni dla powonieni

i dalej Lasocki brnie w opis okropności, z fizjologii skazańców zrodzony:

Oto na noc wnoszą zwykle do każdej sali olbrzymią kadź drewnianą ,parasz” zwaną jako zbiornik do zaspokajania wszelkich potrzeb naturalnych. Można sobie wyobrazić, czem są owe kadzie, dziesiątkami lat niezmieniane, całe inkrustowane solami amoniakalnemi i gromadzące w sobie w ciągu nocy płynne i stałe ekskrecje kilkuset często ludzi. Co się więc dzieje z powonieniem i próżnią ust ludzi, przywykłych do warunków więcej higienicznych, nawet u względnie najbiedniejszych więźniów stanu, tego mówić nie potrzebuję̧

Innym przykładem może być relacja Zygmunta Kierdeja, który dość dużą część swoich wspomnień poświęca właśnie opisowi drogi na zesłanie. Wyruszył on z Warszawy do Petersburga, dalej do Solwyczegodska w obwodzie archangielskim, który być może w sensie geograficznym nie znajduje się na Syberii, lecz, jak już wspomniałem, bez wątpienia wpisuje się w funkcjonującą w świadomości Polaków definicję Syberii jako miejsca zesłania. Wysłany z Petersburga etapami na północ Rosji, zaznaczał, że nie tylko zmęczenie w podróży dawało się we znaki, ale również i okropny mróz:

Gdyśmy przejeżdżali przez miasto powiatowe [...], posługacz hotelowy [...] mówił, że dnia tego rano było 42 stopnie zimna. To też o zimnie takiem ci tylko mogą mieć wyobrażenie, którzy je znosić byli przymuszeni ${ }^{35}$.

Warto również wspomnieć o postaci Jana Siwińskiego, który, tak jak Ludwik Zielonka, za udział w powstaniu styczniowym zesłany został na 8 lat ciężkich robót w kopalniach Nerczyńskich Kraju Zabajkalskiego. Więziony w Cytadeli Warszawskiej, wysłany standardowo najpierw do Petersburga, a następnie do Moskwy i Niżnego Nowogrodu, by dotrzeć przez Kazań, Krasnojarsk i Irkuck na miejsce. $Z$ jego opisu drogi warto przytoczyć poruszaną już tutaj problematykę granicy pomiędzy Europą i Azją. Otóż Siwiński tak pisze o tym podniosłym momencie:

Tu jest granica Europy i Azyi. Tu są dwa słupy murowane, owe martwe świadki ludzkich westchnień, łez i boleści! Tu każdy a każdy Europejczyk klęka przy słupie europejskim i żegna się - żegna się na długo, żegna się na wieki! Ten słup jest personifikacją i kraju i ziemi rodzinnej, przyjaciół i kochanek. [...] Ile ludzi tu łzy wylewało - wie tylko Bóg! ${ }^{36}$.

${ }^{34}$ W. Lasocki, Wspomnienia z mojego życia, t. 2, Kraków 1934, s. 13-14.

35 Z. Kierdej, Wspomnienia z wygnania 1865-1874, Poznań 1875, s. 8-9.

36 J. Siwiński, Katorżnik czyli Pamiętniki Sybiraka, Kraków 1905, s. 45. 
W kwestii opisów drogi na zesłanie stwierdzić należy, że przedstawione powyżej opisy nie są oczywiście jedynymi, można ich jeszcze wskazać dziesiątki innych, w tym barwne pozostawione przez Wandalina Czernika czy też Władysława Zapałowskiego. Każdy z nich, obok cech wspólnych, jest ze swej strony swoistym indywidualnym przeżyciem każdego z zesłańców.

Podsumowując, w ramach problemu drogi na zesłanie (czy to na Wschodnią, czy Zachodnią Syberię, lub też do północnych guberni rosyjskich) pojawia się wiele pomniejszych tematów, nad którymi można przeprowadzić osobne badania, bowiem materiału, choćby w postaci samych pamiętników, jest wiele, a sporo z nich jeszcze czeka na swoich badaczy. Wymienić należy takie mikrohistoryczne zagadnienia jak: kwestia psychiki zesłańczej, społeczności partii aresztanckich, warunki życia, jeśli chodzi o historię materialną, jak również przytaczany już tutaj problem granicy geograficznej, granicy będącej zarazem metaforą człowieczeństwa i wolności. Wreszcie, z każdego opisu emanuje z jednej strony ból, głód, zimno, cierpienie fizyczne i mentalne. $Z$ drugiej zaś, zdarzały się i pozytywne, podnoszące na duchu sytuacje, których pamiętnikarze nie omieszkali zanotować tak w swojej pamięci, jak i na kartach swoich wspomnień. Wszystko to składa się na obraz indywidualnych przeżyć z drogi zesłańca, jak również rzeczywistości go otaczającej, najczęściej wspólnej i dla pozostałych zesłańców.

Eukasz Wotczyk

\title{
KORNEL'S AND LUDWIK'S ZIELONKA ON THE WAY TO SIBERIA RUSSIA IN THE EYES OF POST-JANUARY UPRISING EXILES
}

\begin{abstract}
$\mathrm{T}$ he period of the nineteenth century is particularly interesting, because it was then that many memories of the exile and the aforementioned trip to exile were created. Observations of Poles-exiles are very interesting because they contain a lot of information about, among others the relation of the Siberia population to the exiles, as well as the perception of reality by the exiles themselves. Interesting are also information on the contacts of exiles with the administration of the Russian Empire.

Particularly interesting are the memories of brothers Ludwik Zielonka and Kornel Zielonka, who took part in the January Uprising, for which they were sent to Eastern Siberia. They both describe the hardships of travel, they cite situations with which they had contact. While Kornel feels great as a writer, Ludwik cites mostly dry facts. Both diaries have one more interesting property: they can be used to examine the way differences in the perception of the reality of exile are found by diametrically different brothers who are in very similar realities.
\end{abstract}

Słowa kluczowe: zesłańcy, Syberia, Rosjanie, pamiętniki

Keywords: exiles, Siberia, Russians, diaries 


\section{BIBLIOGRAFIA}

Etapami na Syberyę. Obrazy i wspomnienia, Warszawa 1916.

Janik M., Dzieje Polaków na Syberii, Kraków 1928.

Kaczyńska E., Syberia: największe więzienie świata (1815-1914), Warszawa 1991.

Kierdej Z., Wspomnienia z wygnania 1865-1874, Poznań 1875.

Kuczyński A., Syberia. Czterysta lat polskiej diaspory, Wrocław 1993.

Lasocki W., Wspomnienia z mojego życia, t. 2, oprac. M. Janik, F. Kopera, Kraków 1933.

Librowicz Z., Polacy w Syberii, Kraków 1884.

Maksimow S., Syberya i ciężkie roboty, Warszawa 1899.

Semenov E., Ku pamięci Aleksandra Despot Zenowicza w Kiachcie, „Rodacy. Pismo Syberyjskie Kongresu Polaków w Rosji", nr 1 (54), 2011, www.rodacynasyberii.pl.

Siwiński J., Katorżnik czyli pamiętniki Sybiraka, Kraków 1905.

Śliwowska W., Ucieczki z Sybiru, Warszawa 2005.

Zielonka K., Wspomnienia z powstania 1863 roku i z życia na wygnaniu w Syberyi, Lwów 1913.

Zielonka L., Wspomnienia z Syberji od r. 1863-1869, Lwów 1886.

Ядринцев Н.К., Сибирь как колония, Санкт-Петербург 1892. 